\title{
Helicobacter pylori and Host Response
}

\author{
Mario M. D'Elios ${ }^{1}$ and Marina de Bernard ${ }^{2}$ \\ ${ }^{1}$ Department of Internal Medicine, University of Florence \\ ${ }^{2}$ Venetian Institute of Molecular Medicine, University of Padua \\ Italy
}

\section{Introduction}

Helicobacter pylori, a pathogen infecting the gastric antrum of half of the adult population worldwide, is thought to be the major cause of acute and chronic gastroduodenal pathologies, including gastric and duodenal ulcer, gastric cancer and gastric B-cell lymphoma of mucosa-associated lymphoid tissue (MALT) (Marshall et al., 1994; Parsonnet et al., 1991; Wotherspoon et al., 1991). Despite a vigorous humoral response against $H$. pylori antigens, most of infected subjects fails to eliminate the pathogen spontaneously. As in other infectious diseases, besides the virulence of the pathogen, both the natural and the specific immune responses of the host are crucial for determining the outcome of the infection. The immune system has evolved different defence mechanisms against pathogens. The first defensive line is provided by 'natural' immunity, including phagocytes, $\mathrm{T}$ cell receptor (TCR) $\gamma \delta+$ T cells, natural killer (NK) cells, mast cells, neutrophils and eosinophils, as well as complement components and pro-inflammatory cytokines, such as interferons (IFNs), interleukin (IL)-1, IL-6, IL-12, IL-18 and tumor necrosis factor (TNF)- $\alpha$. The more specialized TCR $\alpha \beta+$ T lymphocytes provide the second defence wall. These cells account for the specific immunity, which results in specialized types of immune responses which allow vertebrates to recognize and clear (or at least control) infectious agents in different body compartments. Viruses growing within infected cells, are faced through the killing of their host cells by CD8+ cytotoxic T lymphocytes (CTL). Most of microbial components are endocytosed by antigen-presenting cells (APC), processed and presented preferentially to CD4+ T helper (Th) cells. Th cells co-operate with B cells for the production of antibodies which opsonize extracellular microbes and neutralize their exotoxins. This branch of the specific Th cell-mediated immune response is known as humoral immunity. Other microbes, however, survive within macrophages in spite of the unfavorable microenvironment and antigen-activated CD4+ Th cells are required to activate macrophages, whose reactive metabolites and TNF- $\alpha$ finally lead to the destruction of the pathogens. This branch of the specific Th cell-mediated response is known as cell-mediated immunity (CMI).

Most of successful immune responses involve both humoral and cell-mediated immunity. CD4+ Th cells can develop different polarized patterns of cytokine production, such as type1 or Th1, type-2 or Th2, type-17 or Th17 (Mosmann et al., 1986; Del Prete et al., 1991; Korn et al., 2009). 
Th1 cells produce IFN- $\gamma$, IL-2 and TNF- $\beta$, elicit macrophage activation and delayed-type hypersensitivity (DTH) reactions, whereas Th2 cells produce IL-4, IL-5, IL-10 and IL-13, which act as growth/differentiation factors for B cells, eosinophils and mast cells and inhibit several macrophage functions (Del Prete, 1998). A new subset of Th cells, named Th17 cells, producing IL-17 alone or in combination with IFN- $\gamma$, has been identified recently (Weaver et al., 2006). Th17 cells play a critical role in protection against microbial challenges, particularly extracellular bacteria and fungi (Bettelli et al., 2007).

However, most of $\mathrm{T}$ cells do not express a polarized cytokine profile; such $\mathrm{T}$ cells (coded as Th0) represent a heterogenous population of partially differentiated effector cells consisting of multiple subsets which secrete different combinations of both Th1 and Th2 cytokines. The cytokine response at effector level can remain mixed or further differentiate into the Th1 or the Th2 pathway under the influence of polarizing signals from the microenvironment. Human Th1 and Th2 cells e.g. also differ for their responsiveness to cytokines. Both Th1 and Th2 cells proliferate in response to IL-2, but Th2 are more responsive to IL- 4 than Th1; on the other hand IFN- $\gamma$ tend to inhibit the proliferative response of Th2 cells (Del Prete et al., 1993). Th1 and Th2 cells substantially differ for their cytolytic potential and mode of help for B-cell antibody synthesis. Th2 clones, usually devoid of cytolytic activity, induce IgM, IgG, IgA, and IgE synthesis by autologous B cells in the presence of the specific antigen, with a response which is proportional to the number of Th2 cells added to B cells. In contrast, Th1 clones, most of which are cytolytic, provide B-cell help for IgM, IgG, IgA (but not IgE) synthesis at low T-cell/B-cell ratios. At high T-cell/B-cell ratios there is a decline in B-cell help related to the Th1-mediated lytic activity against antigen-presenting autologous B-cells (Del Prete et al., 1991b). Th1 and Th2 cells exhibit different ability to activate cells of the monocyte-macrophage lineage. Th1, but not Th2, help monocytes to express tissue factor (TF) production and procoagulant activity (PCA). In this type of Th cell-monocyte cooperation, both cell-to-cell contact and Th1 cytokines (namely IFN- $\gamma$ ), are required for optimal TF synthesis and PCA, whereas Th2-derived IL-4, IL-10 and IL-13 are strongly inhibitory (Del Prete et al., 1995a).

The factors responsible for the Th cell polarization into a predominant Th profile have extensively been investigated. Current evidence suggests that Th1, Th2 and Th17 cells develop from the same Th-cell precursor under the influence of mechanisms associated with antigen presentation (Kamogawa et al., 1993; Korn et al. 2009). Both environmental and genetic factors influence the Th1 or Th2 differentiation mainly by determining the 'leader cytokine' in the microenvironment of the responding Th-cell. IL-4 is the most powerful stimulus for Th2 differentiation, whereas IL-12, IL-18 and IFNs favor Th1 development (D'Elios et al., 1999). A role has been demonstrated for the site of antigen presentation, the physical form of the immunogen, the type of adjuvant, and the dose of antigen (Constant et al., 1997). Several microbial products (particularly from intracellular bacteria) induce Th1-dominated responses because they stimulate IL-12 production. IFN- $\gamma$ and IFN- $\alpha$ favor the Th1 development by enhancing IL-12 secretion by macrophages and maintaining the expression of functional IL-12 receptors on Th cells (Szabo et al., 1995). IL18 sustains the expression of IL-12R $\beta$, indicating that IL-12 and IL-18 synergize in inducing and maintaining Th1 development (Xu et al., 1998). On the other hand, IL-11 and PGE2 would promote Th2 cell polarization (D'Elios et al., 1999). Other microbial products and stimuli induce a preferential activation of Th17 responses (Codolo et al., 2008a; Korn et al., 2009). 


\section{Immune responses in $\boldsymbol{H}$. pylori infection}

\subsection{Innate reponses in $\boldsymbol{H}$. pylori infection}

Most of $H$. pylori-infected patients are unable to clear the pathogen, leading to postulate that $H$. pylori might somehow hamper the host immune response. It has been shown that $H$. pylori may interfere with protective immunity by acting on professional APC through the release of its vacuolating cytotoxin (VacA), which impairs antigen processing and the subsequent priming of efficient immune response (Molinari et al., 1998). The failure of clearing $H$. pylori from the gastric environment almost invariably leads to chronic antral gastritis. Colonization of the stomach by $H$. pylori is consistently accompanied by inflammation of the gastric mucosa, which varies according to the host immune reaction against the pathogen. Once in the stomach, H. pylori first activates the natural immunity cellular compartment, represented by macrophages and neutrophils. IL-8 expression by gastric epithelium following contact with $H$. pylori plays a major role in the initial host response to the bacterium, since this chemokine acts as a strong chemotactic and activating factor for neutrophils, which in turn contribute to initiate and expand the inflammatory cascade (Crabtree et al., 1993). Furthermore, certain H. pylori components, such as HP-NAP, the lipopolysaccharide, VacA or the cytotoxin-associated protein CagA, as well as the urease or the heat shock proteins (HSP) are allowed to cross the damaged layer of gastric cells and to come in contact with macrophages. Activation of macrophages, mainly exerted by HPNAP, results in the release of several cytokines, including IL-12, IL-1, IL-6, TNF- $\alpha$, IFN- $\alpha$ and chemokines, such as IL-8. Moreover, also neutrophils are able to produce IL-12 and IL23 in response to HP-NAP (Amedei et al, 2006). This is an important step of the natural history of $H$. pylori infection, because the local cytokine "milieu", particularly the IL-12 and IL-23 produced by cells of the natural immunity is crucial in driving the subsequent specific T-cell response into a more or less polarized Th1 pattern. Furthermore H. pylori may results in activation not only of TLR receptor (e.g. by HP-NAP) but also of the cytoplasmic nucleotide-binding oligomerization domain (NOD)1, member of the NOD-like receptors (NLR) family. In particular, H. pylori peptidoglycan, acting in concert with the bacterial type IV "syringe", encoded by the cag PAI, following the engagement of NOD1 in gastric epithelial cells, leads to the generation of protective Th1 responses (Kaparakis et al., 2007; Pritz et al., 2007; Watanabe et al., 2010).

\subsection{Th response in $\boldsymbol{H}$. pylori infection}

The The pattern of cytokines produced by the immunological active cells recruited in the antral mucosa of $H$. pylori -infected patients with peptic ulcer were analyzed by RT-PCR. Antral biopsies from patients with ulcer showed IL-12, IFN- $\gamma$, and TNF- $\alpha$ but not IL-4, mRNA expression, whereas virtually no mRNA encoding for cytokines was found in the mucosa of $H$. pylori -negative controls (D'Elios et al., 1997b). In the same biopsies, immunohistochemistry showed remarkable in vivo activation of IFN- $\gamma$, but not IL-4, producing T cells (D'Elios et al., 1997c).

Several studies have examined the antigen specificity and the cytokines produced by the $H$. pylori-specific Th cells derived from the antral mucosa of $H$. pylori -infected patients. Gastric biopsies were pre-cultured in IL-2-conditioned medium in order to preferentially expand T cells activated in vivo, and T-cell blasts were cloned according to a high efficiency technique allowing the growth of virtually every single T cell (D'Elios et al., 1997). 
In $H$. pylori infected patients the proportion of $H$. pylori -reactive gastric T-cells in each patient was variable, ranging from 2 to $33 \%$ of $\mathrm{CD} 4+$ clones. The majority of gastric-derived $\mathrm{T}$ cells were specific for CagA or for HP-NAP, whereas a minority were specific for VacA, for urease, or for HSP (D'Elios et al., 1997b; Amedei et al., 2006). Among the H. pylori reactive clones from low grade gastric B-cell lymphoma (MALToma), 25\% were specific for urease, $4 \%$ for VacA, and $71 \%$ proliferated only to H. pylori lysate (D'Elios et al., 1999). These data suggest that in MALToma urease is an important target of the gastric T-cell response and that some other still undefined antigens of $H$. pylori may be relevant in driving Th and B-cell activation and proliferation.

In peptic ulcer patients, in vitro stimulation with the appropriate $H$. pylori antigens induced the great majority of $H$. pylori-reactive Th clones to produce IFN- $\gamma$ but not IL-4 (expressing thus a polarized Th1 profile). Under the same experimental conditions, most of H. pylorispecific T-cell clones derived from uncomplicated chronic gastritis showed a Th0 phenotype, producing IL-4 and/or IL-5 together with IFN- $\gamma$, whereas only one third of $H$. pylori-specific gastric T cells was polarized towards the Th1 effectors (D'Elios et al., 1997d). Also in MALToma patients most of $H$. pylori-specific $\mathrm{T}$ cell clones derived from the gastric mucosa were able to produce both Th1 and Th2 cytokines (D'Elios et al., 1999).

Detailed analysis of the antigen-induced B-cell help exerted in vitro by $H$. pylori-reactive gastric T-cell clones provided new information on the mechanisms possibly associated with the onset of low-grade B-cell lymphoma of the gastric MALT, rare complication of chronic $H$. pylori infection. Functional analysis of H. pylori-specific Th clones derived from the gastric antrum of infected patients showed that in vitro stimulation with the appropriate $H$. pylori antigen resulted in the expression of their helper function for B-cell proliferation and Ig production (D'Elios et al., 1997b). This can provide convincing explanation for the intense Bcell activation in the lymphoid tissue associated with, or newly generated in, the antral mucosa during chronic H. pylori infection. Such a sustained H. pylori -induced T celldependent B-cell activation is responsible for the high levels of specific antibodies found in the serum of H. pylori -infected patients (Rathbone et al., 1986; Crabtree et al., 1995). In chronic gastritis patients either with or without ulcer, the helper function to B cells exerted by $H$. pylori antigen-stimulated gastric T-cell clones was negatively regulated by the concomitant cytolytic killing of B cells (D'Elios et al., 1997b). In contrast, gastric T-cell clones from MALToma patients were surprisingly unable to down-modulate their antigen-induced help for B cell proliferation (D'Elios et al., 1999). Indeed, none of the gastric H. pylori-specific T-cell clones from MALToma was able to express perforin-mediated cytotoxicity against autologous B cells. Moreover, most Th clones from uncomplicated chronic gastritis induced Fas-Fas ligand-mediated apoptosis in target cells, whereas only a minority of H. pylori specific gastric clones from MALToma patients were able to induce apoptosis in target cells, including autologous B cells (D'Elios et al., 1999).

There are a number of postulated mechanisms whereby H. pylori can induce mucosal injury, and some are certainly related to many of the $H$. pylori pathogenic products described (Telford et al., 1994; Tomb et al., 1997). Indeed in many infectious (and non-infectious) diseases, the type of immune response elicited is important for protection, but, under certain circumstances, it may also contribute to the pathogenesis of disease. A number of studies from different research groups seem to agree on that Th1 polarization of immune response to H. pylori is associated with more severe disease (D'Elios et al., 1997b; Hauer et al., 1997; Bamford et al., 1998; Sommer et al., 1998). Preferential activation of Th1 cells and the 
subsequent production of their cytokines, namely IFN- $\gamma$ and TNF- $\alpha$, in the absence of Th2 cytokines can potentiate gastrin secretion and pepsinogen release, as observed in vitro in animal models (Weigert et al., 1996). Data from our laboratory indicate that also in humans TNF- $\alpha$ and IFN- $\gamma$ are able to dose-dependently stimulate pepsinogen release from isolated gastric chief cells. In this model, simultaneous addition of IL-4 was not synergic, rather inhibitory, on the IFN- $\gamma$-induced pepsinogen release by chief cells, whereas it had no effect on the pepsinogen release induced by TNF- $\alpha$ (D'Elios et al., 1998). Moreover Th1 cells are able to induce both tissue factor production by monocytes (Del Prete et al., 1995a) and the activation of coagulation cascade, followed by microvascular thrombosis and consequent alteration of epithelial cell integrity. A number of studies suggest that chronic inflammation (e.g. triggered by infectious agents like H. pylori) may be important in the pathogenesis of atherothrombosis (Elizalde et al., 1997; Danesh et al., 1997). Indirect support to the hypothesis that the Th1-type of gastric immune response against $H$. pylori contributes to the pathogenesis of peptic ulcer comes from the observation that in kidney graft recipients (undergoing strong immunosuppression) peptic ulcer and active inflammatory lesions were virtually absent, in spite of a higher prevalence of $H$. pylori colonization (Hruby et al., 1997). The results obtained so far clearly demonstrated that gastric T-cell response to H. pylori antigens characterized by a mixed Th1-Th2 cytokine profile is apparently associated with low rate of ulcer complication. The concept that Th2 cytokines, particularly IL- 4 and IL-10, are important in balancing and quenching some immunopathological effects of polarized Th1 responses is supported by other clinical and experimental observations. Holding in mind the concept of Th1/Th2 balance, one may reconsider what clinicians know from a long time, that, during pregnancy, patients suffering of peptic ulcer significantly reduce their dyspeptic symptoms and tend to undergo remission for the time of pregnancy (Cappell et al., 2003). This might be an indirect effect of the preferential Th2 "switch" occurring in pregnancy, which makes the mother able to "tolerate" her offspring by inhibiting Th1 responses, which would otherwise promote "graft" (fetus) rejection.

In favor of a role for the immune system in influencing gastric acid secretion and the onset of peptic ulcer disease is the interesting observation in rats that immune cells of gastric mucosa, but not epithelial cells, expressed in vivo detectable mRNA for gastrin, muscarine and histamine receptors. Such information supports the hypothesis that the primary target of antiulcer drugs may primarily be the immune cells in the gastric environment (Mezey et al., 1992). Many studies performed in mice demonstrated that T-cell dependent immune response are needed for protection against $H$. pylori whereas antibody response is not strictly required for protective immunity (Ermak et al., 1998). However if the T-cell response induced against $H$. pylori is not appropriate it may even result in a damage for the host, as demonstrated by several reports also in animal models. Transferring $\mathrm{T}$ cells derived from $H$. pylori infected patients into SCID mice has proven to be effective in inducing gastric ulcer in those mice, thus demonstrating that host immunity is involved in the development of peptic ulcers (Yokota et al., 1999). In H. felis -infected mice, neutralization of IFN- $\gamma$ significantly reduced the severity of gastritis, strongly supporting the concept that preferential activation of a Th1-type response, far from being protective, rather contributes to the development and maintenance of gastric immunopathology. The magnitude of $H$. felis -induced inflammation in IL-4-deficient mice was higher than in their wild-type counterparts. Moreover, infection with $H$. felis induced minimal inflammation in BALB/c mice, whose genetic background is prone to high IL-4 production in response to different antigens. The results of these studies 
provide further evidence that a polarized Th1 response is associated with gastric inflammation and disease whereas, when a mixed Th1/Th2 response is raised, it is able to reduce the unbalanced proinflammatory Th1 response (Mohamadi et al., 1996). If the hypothesis that some local IL-4 production may result in protection from ulcer is correct, the so-called "African enigma" (i.e. discrepancy between high rate of $H$. pylori infection and low prevalence of peptic ulcer)(Holcombe et al., 1992) may be explained, at least in part, on the basis of the acquired cytokine background of African people living in endemic areas of helminth infection, which is known to elicit strong and persistent Th2-dominated responses. Theoretically, a Th2-oriented host immunological background would be a misfortune for efficient defence against mycobacteria, but would provide at the same time an advantage for developing milder responses to a pathogen like H. pylori, so widespread even in infancy. Thus, peptic ulcer may be regarded as the immunopathological outcome of a chronic inflammatory process induced by some $H$. pylori strains in subjects genetically and/or environmentally biased to develop strong Th1-polarized responses.

Although related to $H$. pylori infection, low-grade gastric MALT lymphoma is a very rare complication and represents a model to study the interplay between chronic infection, immune response and lymphomagenesis. This type of lymphoma represents the first described neoplasia susceptible to regression following antibiotic therapy resulting in $H$. pylori eradication (Wotherspoon et al., 1993). A prerequisite for lymphomagenesis is the development of secondary inflammatory MALT induced by chronic H. pylori challenge (Isaacson, 1994). The tumor cells of low-grade gastric MALT lymphoma are memory B cells still responsive to differentiation signals, such as CD40 costimulation and cytokines produced by antigen-stimulated $\mathrm{T}$ helper cells, and dependent for their growth on the stimulation by H. pylori -specific T cells (Hussel et al., 1996; Greiner et al., 1997). In early phases, this tumor is sensitive to withdrawal of $H$. pylori -induced T-cell help, providing an explanation for both the tumor tendency to remain localized to the primary site and its regression after $H$. pylori eradication with antibiotics (Wotherspoon et al., 1993; Bayerdoffer et al., 1995). The growth of neoplastic B cells may depend on evasion from T cell-mediated cytotoxicity. In this regard, gastric T cells from MALT lymphoma showed both defective perforin-mediated cytotoxicity and poor ability to induce Fas-Fas ligand-mediated apoptosis, thus providing a possible explanation for their enhanced helper activity on B-cell proliferation. Both defects were restricted to MALT lymphoma-infiltrating T cells, since specific $T$ helper cells from peripheral blood of the same patients expressed the same degree of either cytolytic potential or pro-apoptotic activity as T cells from chronic gastritis patients (D'Elios et al., 1999). The reason why gastric T cells of MALT lymphoma, while delivering full help to B cells, are apparently deficient in mechanisms involved in the concomitant control of B-cell growth, remains unclear. It has been shown that VacA toxin inhibits antigen processing in APC, but not the exocytosis of perforin-containing granules of NK cells (Molinari et al., 1998). It is possible that, in some H. pylori -infected individuals, other bacterial components affect the development or the expression in gastric $\mathrm{T}$ cells of regulatory cytotoxic mechanisms on B-cell proliferation, allowing exhaustive and inbalanced B-cell help and lymphomagenesis to occur.

\subsection{H. pylori, asthma and allergy}

The severity and incidence of asthma have increased drastically in the developed nations of the world over the last decades. Although the underlying reason is still unknown, clinical, 
epidemiological and experimental evidence indicate that infectious diseases can influence the development of allergic disorders (Strachan et al., 1989; Roumier et al., 2008). Accordingly, an inverse correlation has been demonstrated between the onset of allergic disorders and the incidence of infections. This may be the result of an inhibition of allergic Th2 inflammation exerted by Th1 responses; the latter are elicited by infectious agents and are able to induce the production of IFN-g, IL-12, IL-18 and IL-23 (Herz et al, 2000). This view is supported by studies showing that development of asthma can be prevented in animals by administering live or killed bacteria or their components, which induce Th1 responses (Wohlleben et al., 2006). We demonstrated that $H$. pylori inhibited Th2 responses in asthmatic patients (Amedei et al., 2006). Interestingly, on the basis of large epidemiological studies, a consistent negative association between $H$. pylori infection and the presence of allergic disorders, such as asthma and rhinitis, has recently been proposed (Chen et al., 2007). Although it is an undoubtedly interesting theory, no convincing molecular mechanism has been suggested to support it.

Our studies carried out with $H$. pylori may help in the understanding of this complex issue. We have shown that the addition of the H. pylori protein HP-NAP to allergen-induced T-cell lines derived from allergic asthmatic patients led to a drastic increase in IFN- $\gamma$-producing $\mathrm{T}$ cells and to a decrease in IL-4-secreting cells, thus resulting in a redirection of the immune response from a Th2 to a Th1 phenotype (Amedei et al., 2006). These results suggest that HP-NAP might be the key element responsible for the decrement of allergy frequency in $H$. pylori-infected patients. Several studies were devoted to the definition of new immunemodulating factors able to inhibit Th2 responses and consequently, different compounds have been proposed for the treatment and prevention of asthma, including several TLR ligands mimicking the effects of microbial components, such as dsRNA, CpGoligodeoxynucleotides and imidazoquinolines (Hirota et al., 2002; Trujillo-Vargas et al., 2005).

We demonstrated that in allergic asthmatic patients, the typical Th2 responses can be redirected toward Th1 by HP-NAP and that the activity of HP-NAP required the engagement of TLR2 (Amedei et al., 2006; Codolo et al., 2008b). To address whether HP$\mathrm{NAP}$, on the basis of its immune-modulating activity, could be beneficial for the prevention and treatment of bronchial asthma, it was administered via the intraperitoneal or the intranasal route using a mouse model of allergic asthma induced by inhaled ovalbumin (OVA). Groups of nine C57BL/6j, wild-type or tlr2-/- mice were treated with OVA alone, or with OVA plus HP-NAP administered intraperitoneally or mucosally. In both systemic and mucosal protocols, mice were treated with OVA according to a standardized procedure consisting of a first phase of sensitization with intraperitoneal OVA and a second phase of induction of the allergic response with aerosolized OVA on day 8 , followed by repeated aerosol challenge with the allergen on days 15-18. Control animals were injected with phosphate-buffered saline (PBS) alone and then exposed to aerosolized PBS. In the systemic protocol, mice were treated with intraperitoneal HP-NAP on day 1 , whereas in the mucosal protocol mice received intranasal HP-NAP on days 7 and 8 (Codolo et al., 2008b).

After priming and repeated aerosol challenge with OVA, Th2 responses were induced in the mouse lung. Accordingly, following OVA treatment, eosinophils were recruited and activated in bronchial airways, and serum IgE levels increased. Both systemic and mucosal administration of HP-NAP strongly inhibited the development of airway eosinophilia and bronchial inflammation. Likewise, HP-NAP treatment strongly affected the cytokine release 
in the lung, reducing the production of IL-4, IL-5 and GM-CSF. Systemic HP-NAP also significantly resulted in both the reduction of total serum IgE and an increase in IL-12 plasma levels. However, no suppression of lung eosinophilia and bronchial Th2 cytokines was observed in tlr2-/- mice following HP-NAP treatment (Codolo et al., 2008b). This phenomenon can be explained by the inhibition of the allergic Th2 inflammation seen when Th1 responses are elicited by infectious agents able to induce the production of IFN- $\gamma$, IL-12 and IL-23. HP-NAP, by acting on innate immune cells via TLR2 agonistic interaction, induces an IL-12- and IL-23-enriched milieu, and in such a way it represents a key factor able to induce a Th2-Th1 redirection. Furthermore, HP-NAP administration in vivo resulted in inhibition of the typical Th2-mediated bronchial inflammation of allergic bronchial asthma. Thus, combined, these results support the view that the increased prevalence and severity of asthma and allergy in Western countries may be related, at least in part, to the decline of $H$. pylori infection, which is able to induce a long-lasting Th1 background, and suggest that the use of a microbial product derived from H. pylori, such as as HP-NAP, may help the prevention and treatment of bronchial asthma and allergic diseases. At the same time, we do not suggest infecting people with $H$. pylori or leaving a $H$. pylori infection without antibiotic treatment to treat asthma and allergy.

\section{Conclusion}

Helicobacter pylori infects almost half of the population worldwide and represents the major cause of gastroduodenal diseases, such as duodenal and gastric ulcer, gastric adenocarcinoma, autoimmune gastritis, and B-cell lymphoma of mucosa-associated lymphoid tissue. Different bacterial and environmental factors, other concomitant infections, and host genetics may influence the balance between mucosal tolerance and inflammation in the course of $H$. pylori infection. Helicobacter pylori induces the activation of a complex and fascinating cytokine and chemokine network in the gastric mucosa. The type of innate and acquired immune responses provides an useful model for explaining both different types of protection and the pathogenetic mechanisms of several disorders elicited by H. pylori. A predominant $H$. pylori-specific Th1 response, characterized by high IFN- $\gamma$, TNF- $\alpha$, and IL-12 production associates with peptic ulcer, whereas combined secretion of both Th1 and Th2 cytokines are present in uncomplicated gastritis. Gastric T cells from MALT lymphoma exhibit abnormal help for autologous B-cell proliferation and reduced perforin- and Fas-Fas ligand-mediated killing of B cells. In $H$. pylori-infected patients with autoimmune gastritis cytolytic T cells infiltrating the gastric mucosa cross-recognize different epitopes of $H$. pylori proteins and $\mathrm{H}^{+} \mathrm{K}^{+}$ATPase autoantigen. An inverse association between $H$. pylori prevalence and the frequencies of asthma and allergies was demonstrated, and the Neutrophil Activating Protein of $H$. pylori, according to its ability in inhibiting allergic inflammation of bronchial asthma, could be the factor responsible for this negative relationship. Given that resistance to antibiotic is increasing and the effectiveness of current therapeutic regimens is decreasing the design of an efficient vaccine for $H$. pylori will represent a novel and very important tool against both infection, peptic ulcer and gastric cancer.

\section{Acknowledgment}

This work was supported in part by MIUR PRIN 2008 to M.M.D.E., and by MIUR PRIN 2006 and Research Grant by University of Padova (CPDA074121/07) to M.d.B. 


\section{References}

Amedei, A., Cappon, A., Codolo, G., Cabrelle, A., Polenghi, A.,Benagiano, M., Tasca, E., Azzurri, A., D'Elios, M.M., Del Prete, G. \& De Bernard, M. (2006). The neutrophilactivating protein of Helicobacter pylori promotes Th1 immune responses. The Journal of Clinical Investigation, Vol.116, No.4, (April 2006), pp. 1092-1101, ISSN 0021-9738

Bacon, C.M., Petricoin, E.F., Ortaldo, J.E., Rees, R.C., Larner, A.C., Johnston, J.A., \& O'Shea, J.J. (1995). Interleukin 12 induces tyrosine phosphorylation and activation of STAT4 in human lymphocytes. Proceedings of the National Academy of Sciences of the United States of America, Vol.92, No.16, (August 1995), pp. 7307-7311

Bamford, K.B., Fan, X., Crowe, S.E., Leary, J.F., Gourley, W.K., Luthra, G.K., Brooks, E.G., Graham, D.Y., Reyes, V.E., \& Ernst, P.B. (1998). Lymphocytes in the human gastric mucosa during Helicobacter pylori have a $\mathrm{T}$ helper cell 1 phenotype. Gastroenterology, Vol.114, No.3, (March 1998), pp. 482-492, ISSN 0016-5085

Bayerdoffer, E., Neubauer, A., Rudolph, B., Thiede, C., Lehn, N., Eidt, S., \& Stolte, M. (1995). Regression of primary gastric lymphoma of mucosa-associated lymphoid tissue after cure of Helicobacter pylori infection. Lancet, Vol.345, No.8965, (June 1995), pp. 1591-1594, ISSN 0140-6736

Bettelli, E., Oukka, M. \& Kuchroo, V.K. (2007) Th-17 cells in the circle of immunity and autoimmunity. Nature Immunology, Vol.8, No.4, (April 2007), pp. 345-350, ISSN 1529-2908

Cappell, M.S. (2003) Gastric and duodenal ulcers during pregnancy. Gastroenterology Clinics of North America, Vol.27, No.1, (March 2003), pp. 263-308, ISSN 0889-8553

Chen, Y., Blaser, M.J. (2007). Inverse associations of Helicobacter pylori with asthma and allergy. Archives of Internal Medicine, Vol.167, No.8, (April 2007), pp. 821-827, ISSN 0003-9926

Codolo, G., Amedei, A., Steere, A.C,. Papinutto, E., Cappon, A., Polenghi, A., Benagiano, M., Paccani, S.R., Sambri, V., Del Prete, G., Baldari, C.T., Zanotti, G., Montecucco, C., D'Elios, M.M. \& de Bernard, M. (2008). Borrelia burgdorferi-NapA driven Th17 cell inflammation in Lyme arthritis. Arthritis and Rheumatism, Vol.58, No.11, (November 2008), pp. 3609-3617, ISSN 0004-3591

Codolo, G., Mazzi, P., Amedei, A., Del Prete, G., Berton, G., D’Elios, M.M. \& de Bernard, M. (2008). The neutrophil-activating protein of Helicobacter pylori down-modulates Th2 inflammation in ovalbumin-induced allergic asthma. Cellular Microbiology, Vol.10, No.11, (November 2008), pp. 2355-2363, ISSN 1462-5814

Constant, S.L. \& Bottomly, K. (1997). Induction of Th1 and Th2 CD4+ T cell responses: The alternative approaches. Annual Review of Immunology, Vol.15, (1997), pp. 297-322, ISSN 0732-0582

Cover, T.L. \& Blaser, M.J. (1996). Helicobacter pylori infection, a paradigm for chronic mucosal inflammation: pathogenesis and implications for eradication and prevention. Advances in Internal Medicine, Vol.41, (1996), pp. 85-117

Crabtree, J.E., Peichl, P., Wyatt, J.I., Stachl, U. \& Lindley, I.J. (1993). Gastric interleukin-8 and IgA IL-8 autoantibodies in Helicobacter pylori infection. Scandinavian Journal of Immunology, Vol.37, No.1, (January 1993), pp. 65-70, ISSN 0300-9475 
Crabtree, J.E., Eyre, D., Levy, L., Covacci, A., Rappuoli, R. \& Morgan, A.G. (1995). Serological evaluation of Helicobacter pylori eradication using recombinant CagA protein. Gut. 36:A46, ISSN 0017-5749

Dallman, M.J. (1995). Cytokines and transplantation: Th1/Th2 regulation of the immune response to solid organ transplants in the adult. Current Opinion in Immunology, Vol. 7, No.5, (October 1995), pp. 632-638, ISSN 0952-7915

Danesh, J., Collins, R., \& Peto, R. (1997). Chronic infections and coronary heart disease: is there a link? Lancet, Vol.350, No.9075, (August 1997), pp. 430-436, ISSN 0140-6736 D'Elios, M.M., Josien, R., Manghetti, M., Amedei, A., De Carli, M., Cuturi, M.C., Blancho, G., Buzelin, F., Del Prete, G. \& Soulillou, J.P. (1997). Predominant Th1 infiltration in acute rejection episodes of human kidney grafts. Kidney International, Vol.51, No.6, (June 1997), pp. 1876-1884, ISSN 0085-2538

D'Elios, M.M., Manghetti, M., De Carli, M., Costa, F., Baldari, C.T., Burroni, D., Telford, J.L., Romagnani, S. \& Del Prete, G. (1997). Th1 effector cells specific for Helicobacter pylori in the gastric antrum of patients with peptic ulcer disease. Journal of Immunology, Vol.158, No.2, (January 1997), pp. 962-967, ISSN 0022-1767

D'Elios, M.M., Romagnani, P., Scaletti, C., Annunziato, F., Manghetti, M., Mavilia, C., Parronchi, P., Pupilli, C., Pizzolo, G., Maggi, E., Del Prete, G. \& Romagnani S. (1997). In vivo CD30 expression in human diseases with predominant activation of Th2-like T cells. Journal of Leukocyte Biology, Vol.61, No.5, (May 1997), pp. 539- 544, ISSN 0741-5400

D'Elios, M.M., Manghetti, M., Almerigogna, F., Amedei, A., Costa, F., Burroni, D., Baldari, C.T., Romagnani, S., Telford, J.L. \& Del Prete, G. (1997). Different cytokine profile and antigen-specificity repertoire in Helicobacter pylori-specific $\mathrm{T}$ cell clones from the antrum of chronic gastritis patients with or without peptic ulcer. European Journal of Immunoogy, Vol.27, No.7, (july 1997), pp. 1751-1755, ISSN 0014-2980

D'Elios, M.M., Andersen, L.P., \& Del Prete, G. (1998). Inflammation and host response. The year in Helicobacter pylori. Current Opinion in Gastroenterology, Vol.14, (1998), pp. 15-19, ISSN 0267-1379 D’Elios, M.M., Amedei, A., Manghetti, M., Costa, F., Baldari, C.T., Quazi A.S., Telford, J.L., Romagnani, S. \& Del Prete, G. (1999). Impaired T-cell regulation of B-cell growth in Helicobacter pylori-related gastric low-grade MALT lymphoma. Gastroenterology, Vol.117, No.5, (November 1999), pp. 1105-1112, ISSN 0016-5085

D'Elios, M.M. \& Del Prete, G. (1999). Th1/Th2 cytokine network. Topics in Neuroscience, Martino, G. \& Adorini, L., eds. Springer-Verlag, Berlin, pp. 68-82 Del Prete, G., De Carli, M., Mastromauro, C., Macchia, D., Biagiotti, R., Ricci, M. \& Romagnani, S. (1991). Purified protein derivative of Mycobacterium tuberculosis and excretorysecretory antigen(s) of Toxocara canis expand in vitro human T cells with stable and opposite (type $1 \mathrm{~T}$ helper or type $2 \mathrm{~T}$ helper) profile of cytokine production. The Journal of Clinical Investigation, Vol.88, No.1, (July 1991), pp. 346-351, ISSN 00219738

Del Prete, G.F., De Carli, M., Ricci, M., \& Romagnani, S. (1991). Helper activity for immunoglobulin synthesis of T helper type 1 (Th1) and Th2 human T cell clones: the help of Th1 clones is limited by their cytolytic capacity. The Journal of Experimental Medicine, Vol.174, No.4, (October 1991), pp. 809-813, ISSN 0022-1007 
Del Prete, G., De Carli, M., Almerigogna, F., Giudizi, M.G., Biagiotti, R. \& Romagnani, S. (1993). Human IL-10 is produced by both type 1 helper (Th1) and type 2 helper (Th2) $\mathrm{T}$ cell clones and inhibits their antigen-specific proliferation and cytokine production. Journal of Immunology, Vol.150, No.2, (January 1993), pp. 353-360, ISSN 0022-1767

Del Prete, G., De Carli, M., Lammel, R.M., D'Elios, M.M., Daniel, K.C., Giusti, B., Abbate, R. \& Romagnani S. (1995). Th1 and Th2 T-helper cells exert opposite regulatory effects on procoagulant activity and tissue factor production by human monocytes. Blood, Vol.86, No.1, (July 1995), pp. 250-257, ISSN 0006-4971

Del Prete, G. (1998). The concept of Type-1 and Type-2 helper T cells and their cytokines in humans. International Reviews of Immunology, Vol.16, No.3-4, (1998), pp. 427-455 Elizalde, J.L., Gomez, J., Panes, J., Lozano, M., Casadevall, M., Ramirez, J., Pizcueta, P., Marco, F., Rojas, F.D., Granger, D.N. \& Pique, J.M. (1997). Platelet activation in mice and human Helicobacter pylori infection. The Journal of Clinical Investigation, Vol.100, No.5, (September 1997), pp. 996-1005, ISSN 0021-9738

Ermak, T.H., Giannasca, P.J., Nichols, R., Myers, G.A., Nedrud, J., Weltzin, R., Lee, C.K., Kleanthous, H. \& Monath, T.P. (1998) Immunization of mice with urease vaccine affords protection against Helicobacter pylori infection in the absence of The Journal of Experimental Medicine, Vol.188, No.12, (December 1998), pp. 2277-2288, ISSN 0022-1007

Ferrick, D.A., Schrenzel, M.D. \& Mulvania T. (1995). Differential production of IFN-ץ and IL-4 in response to Th1- and Th2-stimulating pathogens by gamma delta T cells in vivo. Nature, Vol.373, No.6511, (January 1995), pp. 255-258, ISSN 0028-0836

Fiorucci, S., Santucci, L., Migliorati, G., Riccardi, C., Amorosi, A., Mancini, A., Roberti, R. \& Morelli, A. (1996). Isolated guinea pig gastric chief cells express tumor necrosis factor receptors coupled with the sphingomyelin pathway. Gut., Vol.38, No.2, (February 1996), pp. 182-189, ISSN 0017-5749

Fritz, J.H., Le Bourhis, L., Sellge, G., Magalhaes, J.G., Fsihi, H.,Kufer, T.A., Collins, C., Viala, J., Ferrero, R.L., Girardin, S.E. \& Philpott, D.J.(2007). Nod1-mediated innate immune recognition of peptidoglycan contributes to the onset of adaptive immunity. Immunity, Vol.26, No.4, (April 2006), pp.445-59, ISSN 1074-7613

Greiner, A., Knorr, C., Qin, Y., Sebald, W., Schimpl, A., Banchereau, J. \& Muller-Hermelink, H.K. (1997). Low-grade B cell lymphomas of mucosa-associated lymphoid tissue (MALT-type) require CD40-mediated signaling and Th2-type cytokines for in vitro growth and differentiation. The American Journal of Pathology, Vol.150, No.5, (May 1997), pp. 1583-1593, ISSN 0002-9440

Hauer, A.C., Finn, T.M., MacDonald, T.T., Spencer, J. \& Isaacson, P.G. (1997). Analysis of TH1 and TH2 cytokine production in low grade B cell gastric MALT-type lymphomas stimulated in vitro with Helicobacter pylori. The Journal of Clinical Pathology, Vol.50, No.11, (November 1997), pp. 957-959, ISSN 0021-9746

Herz, U., Lacy, P., Renz, H. \& Erb, K. (2000). The influence of infections on the development and severity of allergic disorders. Current Opinion in Immunology, Vol.12, No.6, (December 2000), pp. 632-640, ISSN 0952-7915

Hirota, K., Kazaoka, K., Niimoto, I., Kumihara, H., Sajiki, H., Isobe, Y., Takaku, H., Tobe, M., Ogita, H., Ogino, T., Ichii, S., Kurimoto, A. \& Kawakami, H. (2002). Discovery 
of 8-hydroxyadenines as a novel type of interferon inducer. Journal of Medicinal Chemistry, Vol.45, No.25, (December 2002), pp. 5419-5422, ISSN 0022-2623

Holcombe, C. (1992). Helicobacter pylori : the African enigma. 1992. Gut. Vol.33, No.4, (April 1992), pp. 429-431, ISSN 0017-5749

Hruby, Z., Myszka-Bijak, K., Gosciniak, G., Blaszczuk, J., Czyz, W., Kowalski, P., Falkiewicz, K., Szymanska, G. \& Przondo-Mordarska, A. (1997). Helicobacter pylori in kidney allograft recipients: high prevalence of colonization and low incidence of active inflammatory lesions. Nephron, Vol.75, No.1, (1997), pp. 25-29 Hussell, T., Isaacson, P.G., Crabtree, J.E. \& Spencer, J. (1996). Helicobacter pylori -specific tumourinfiltrating $\mathrm{T}$ cells provide contact dependent help for the growth of malignant $\mathrm{B}$ cells in low-grade gastric lymphoma of mucosa-associated lymphoid tissue. The Journal of Pathology, Vol.178, No.2 (February 1996), pp. 122-127, ISSN 0022-3417

Isaacson, P.G. (1994). Gastrointestinal lymphoma. Human Pathology, Vol.25, No.10, (October 1994), pp. 1020-1029, ISSN 0046-8177

Kamogawa, Y., Minasi, L.E., Carding, S.R., Bottomly, K. \& Flavell, R.A. (1993). The relationship of IL-4- and IFN- $\gamma$-producing T cells studied by lineage ablation of IL4-producing cells. Cell, Vol.75, No.5, (December 1993), pp. 985-995, ISSN 0092-8674 Kaparakis, M., Philpott, D.J., Ferrero, R.L. (2007). Mammalian NLR proteins; discriminating foe from friend. Immunology and Cell Biology, Vol.85, No.6, (AugustSeptember 2007), pp. 495-502, ISSN 0818-9641

Korn, T., Bettelli, E., Oukka, M., Kuchroo, V.K. (2009). IL-17 and Th17 Cells. Annual Review of Immunology, Vol.27, (2009), pp.485-517 Marshall, B.J. (1994). Helicobacter pylori. Am. J. Gastroenterol. 89: 116-128, ISSN 0002-9270

Mezey, E. \& Palkovits, S. (1992). Localization of targets for anti-ulcer drugs in cells of the immune system. Science, Vol.258, No.5088, (December 1992), pp. 1662-1665, ISSN 0036-8075

Mohammadi, M., Czinn, S., Redline, R. \& Nedrud, J. (1996). Helicobacter-specific cellmediated immune response display a predominant Th1 phenotype and promote a delayed-type hypersensitivity response in the stomachs of mice. Journal of Immunology, Vol.156, No.12, (June 1996), pp. 4729-4738, ISSN 0022-1767

Molinari, M., Salio, M., Galli, C., Norais, N., Rappuoli, R., Lanzavecchia, A. \& Montecucco, C. (1998). Selective inhibition of Ii-dependent antigen presentation by Helicobacter pylori toxin VacA. The Journal of Experimental Medicine, Vol.187, No.1, (January 1998), pp. 135-140, ISSN 0022-1007

Mosmann, T.R., Cherwinski, H., Bond, M.W., Giedlin, M.A. \& Coffman, R.L. (1986). Two types of murine $\mathrm{T}$ cell clone. I. Definition according to profiles of lymphokine activities and secreted proteins. Journal of immunology, Vol.136, No.7, (April 1986), pp. 2348-2357, ISSN 0022-1767 Mosmann, T.R. \& Sad, S. (1996). The expanding universe of T-cell subsets: Th1, Th2 and more. Immunology Today, Vol.17, No.3, (March 1996), pp. 138-146

Niessner, M. \& Volk, B.A. (1995). Altered Th1/Th2 cytokine profiles in the intestinal mucosa of patients with inflammatory bowel disease as assessed by quantitative transcribed polymerase chain reaction (RT-PCR). Clinical and Experimental Immunology, Vol.101, No.3, (September 1995), pp. 428-435, ISSN 0009-9104

Parronchi, P., Romagnani, P., Annunziato, F., Sampognaro, S., Becchio, A., Giannarini, L., Maggi, E., Pupilli, C., Tonelli, F. \& Romagnani, S. (1997). Type 1 T-helper cells 
predominance and interleukin-12 expression in the gut of patients with Crohn's disease. The American Journal of Pathology, Vol.150, No.3, (March 1997), pp. 823-831, ISSN 0002-9440

Parsonnet, J., Friedman, G.D., Vandersteen, D.P., Chang, Y., Vogelman, J.H., Orentreich, N. \& Sibley, R.K. (1991). Helicobacter pylori infection and the risk of gastric cancer. The New England Journal of Medicine, Vol. 325, No.16, (October 1991), pp. 1127-1131, ISSN 0028-4793

Piccinni, M.P., Beloni, L., Livi, C., Maggi, E., Scarselli, G. \& Romagnani, S. (1998). Role of type $2 \mathrm{~T}$ helper (Th2) cytokines and leukemia inhibitory factor (LIF) produced by decidual $\mathrm{T}$ cells in unexplained recurrent abortions. Nature Medicine, Vol.4, No.9, (September 1998), pp. 1020-1024

Rathbone, B.J., Wyatt, J.I., Worsley, B.W., Shires, S.E., Trejdosiewicz, L.K. \& Heatley, R.V. (1986). Systemic and local antibody responses to gastric Campylobacter pyloridis in non-ulcer dyspepsia. Gut, Vol.27, No.6, (June 1986), pp. 642-647, ISSN 0017-5749

Rincon, M. \& Flavell, R.A. (1997). T cell subsets: transcriptional control in the Th1/Th2 decision. Current Biology, Vol.7, No.11, (November 1997), pp. 729-732, ISSN 09609822 Roumier, T., Capron, M., Dombrowicz, D. \& Faveeuw, C. (2008). Pathogen induce regulatory cell populations preventing allergy through the Th1/Th2 paradigm point of view. Immunologic research, Vol.40, No.1, (2008), pp. 1-17, ISSN 0257-277X

Sommer, F., Faller, G., Konturek, P., Kirchner, T., Hahn, E.G., Zeus, J., Röllinghoff, M. \& Lohoff, M. (1998). Antrum- and corpus mucosa-infiltrating CD4(+) lymphocytes in Helicobacter pylori gastritis display a Th1 phenotype. Infection and Immunity, Vol.66, No.11, (November 1998), pp. 5543-5546, ISSN 0019-9567

Strachan, D.P. (1989). Hay fever, hygiene and household size. BMJ Vol.299, No.6710, (November 1989), pp. 1259-1260 Szabo, S., Jacobson, N.G., Dighe, A.S., Gubler, U. \& Murphy, K.M. (1995). Developmental committment to the Th2 lineage by extinction of IL-12 signaling. Immunity, Vol.2, No.6, (June 1995), pp. 665-675, ISSN 1074-7613

Szabo, S.J., Glimcher, L.H. \& Ho, I.C. (1997). Genes that regulate interleukin-4 expression in T cells. Current Opinion in Immunology, Vol.9, No.6, (december 1997), pp. 775-781, ISSN 0952-7915

Telford, J.L., Ghiara, P., Dell'Orco, M., Comanducci, M., Burroni, D., Bugnoli, M., Tecce, M.F., Censini, S., Covacci, A., Xiang, Z., Papini, E., Montecucco, C., Parente, L. \& Rappuoli, R. (1994). Gene structure of the Helicobacter pylori cytotoxin and evidence of its key role in gastric disease. The Journal of Experimental Medicine, Vol.179, No.5, (May 1994), pp. 1653-1670, ISSN 0022-1007

Tomb, J.F., White, O., Kerlavage, A.R., Clayton, R.A., Sutton, G.G., Fleischmann, R.D., Ketchum, K.A., Klenk, H.P., Gill, S., Dougherty, B.A., Nelson, K., Quackenbush, J., Zhou, L., Kirkness, E.F., Peterson, S, Loftus B., Richardson, D., Dodson, R., Khalak, H.G., Glodek, A., McKenney, K., Fitzegerald, L.M., Lee, N., Adams, M.D., Hickey, E.K., Berg, D.E., Gocayne, J.D., Utterback, T.R., Peterson, J.D., Kelley, J.M., Cotton, M.D., Weidman, J.M., Fujii, C., Bowman, C., Watthey, L., Wallin, E., Hayes, W.S., Borodovsky, M., Karp, P.D., Smith, H.O., Fraser, C.M., Venter, J.C. (1997). The complete genome sequence of the gastric pathogen Helicobacter pylori. Nature, Vol.388, No.6642, (August 1997), pp. 539-547, ISSN 0028-0836 
Trinchieri, G. (1995). Interleukin-12: a proinflammatory cytokine with immunoregulatory functions that bridge innate resistance and antigen-specific adaptive immunity. Annual Review of Immunology, Vol.13, (1995), pp. 251-276, ISSN 0732-0582

Trujillo-Vargas, C.M., Mayer, K.D., Bickert, T., Palmetshofer, A., Grunewald, S., RamirezPineda, J.R., Polte, T., Hansen, G., Wohlleben G. \& Erb KJ. (2005). Vaccinations with T-helper type 1 directing adjuvants havedifferent suppressive effects on the development of allergen-induced T-helper type 2 responses. Clinical and Experimental Allergy, Vol. 35, No.8, (August 2005), pp. 1003-1013, ISSN 0954-7894

Weaver, C.T., Harrington, L.E-, Mangan, P.R., Gavriel,i M. \& Murphy, K.M. (2006). Th17: an effector CD4 T cell lineage with regulatory T cell ties. Immunity, Vol.24, No.6, (June 2006), pp. 677-688, ISSN 1074-7613

Weigert, N., Schaffer, K., Schusdziarra, V., Classen, M. \& Schepp, W. (1996). Gastrin secretion from primary cultures of rabbit antral $G$ cells: stimulation by inflammatory cytokines. Gastroenterology, Vol.110, No.1, (January 1996), pp. 147154, ISSN 0016-5085

Wohlleben, G. \& Erb, K.J. (2006). Immune stimulatory strategies for the prevention and treatment of asthma. Current Pharmaceutical Design, Vol.12, No.25, (2006), pp. 32813292 , ISSN 1381-6128

Wotherspoon, A.C., Ortiz-Hidalgo, C., Falzon, M.F. \& Isaacson, P.G. (1991). Helicobacter pylori associated gastritis and primary B-cell lymphoma. Lancet, Vol.338, No.8776, (November 1991), pp. 1175-1176, ISSN 0140-6736

Wotherspoon, A.C., Doglioni, C., Diss, T.C., Pan, L., Moschini, A., De Boni, M. \& Isaacson, P.G. (1993). Regression of primary low grade B cell gastric lymphoma of mucosaassociated lymphoid tissue type after eradication of Helicobacter pylori. Lancet, Vol.342, No.8871, (September 1993), pp. 575-577, ISSN 0140-6736

Yokota, K., Kobayashi, K., Kahawara, Y., Hayashi, S., Hirai, Y., Mizuno, M., Okada, H., Akagi, T., Tsuji, T. \& Oguma, K. (1999). Gastric ulcers in SCID mice induced by Helicobacter pylori infection after transplanting lymphocytes from patients with gastric lymphoma. Gastroenterology, Vol.117, No.4, (October 1999), pp. 893-899, ISSN 0016-5085 


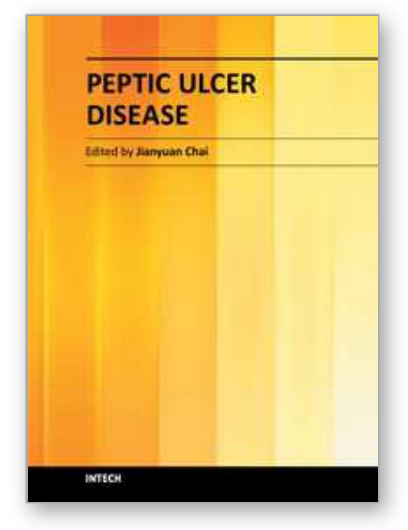

\author{
Peptic Ulcer Disease \\ Edited by Dr. Jianyuan Chai
}

ISBN 978-953-307-976-9

Hard cover, 482 pages

Publisher InTech

Published online 04, November, 2011

Published in print edition November, 2011

Peptic ulcer disease is one of the most common chronic infections in human population. Despite centuries of study, it still troubles a lot of people, especially in the third world countries, and it can lead to other more serious complications such as cancers or even to death sometimes. This book is a snapshot of the current view of peptic ulcer disease. It includes 5 sections and 25 chapters contributed by researchers from 15 countries spread out in Africa, Asia, Europe, North America and South America. It covers the causes of the disease, epidemiology, pathophysiology, molecular-cellular mechanisms, clinical care, and alternative medicine. Each chapter provides a unique view. The book is not only for professionals, but also suitable for regular readers at all levels.

\title{
How to reference
}

In order to correctly reference this scholarly work, feel free to copy and paste the following:

Mario M. D'Elios and Marina de Bernard (2011). Helicobacter pylori and Host Response, Peptic Ulcer Disease, Dr. Jianyuan Chai (Ed.), ISBN: 978-953-307-976-9, InTech, Available from:

http://www.intechopen.com/books/peptic-ulcer-disease/helicobacter-pylori-and-host-response

\section{INTECH}

open science | open minds

\section{InTech Europe}

University Campus STeP Ri

Slavka Krautzeka 83/A

51000 Rijeka, Croatia

Phone: +385 (51) 770447

Fax: +385 (51) 686166

www.intechopen.com

\section{InTech China}

Unit 405, Office Block, Hotel Equatorial Shanghai

No.65, Yan An Road (West), Shanghai, 200040, China

中国上海市延安西路65号上海国际贵都大饭店办公楼405单元

Phone: +86-21-62489820

Fax: $+86-21-62489821$ 
(C) 2011 The Author(s). Licensee IntechOpen. This is an open access article distributed under the terms of the Creative Commons Attribution 3.0 License, which permits unrestricted use, distribution, and reproduction in any medium, provided the original work is properly cited. 